\title{
Information and Communication Technology Based Learning in the 21st Century:
}

\author{
New Challenges in Education Amid Covid-19 Pandemic
}

\author{
Muntari* \\ Study Program of Education Administration \\ Mataram University \\ Mataram, Indonesia \\ *muntari16@unram.ac.id
}

Burhanudin

SDN 1 Dopang, Gunung Sari, West Lombok

West Lombok Regency Education and Culture Office Gerung, Indonesia

buhanudinhburhanudin@gmail.com

\author{
Khaerul Akbar \\ SMPN 2 Praya Barat Daya \\ Central Lombok Regency Education and Culture Office \\ Praya, Indonesia \\ khairulakbar.st@gmail.com
}

Lalu Kamarudin

Study Program of Education Administration

Mataram University

Mataram, Indonesia

lalukamarudin14@gmail.com

\begin{abstract}
This article aims to describe the competencies needed in the $21^{\text {st }}$ century, especially in facing new challenges in education amid the Covid-19 pandemic, both by teacher and students, and also to describe how the strategies so that teachers in Indonesia are literate towards the development of information and communication technology (ICT). Competencies needed by students in the $21^{\text {st }}$ century are critical thinking, communication, collaboration, problem solving, innovation, creativity, adaptation, initiative, entrepreneurial spirit, productivity, flexibility, accountability, self-direction, leadership, responsibility, decision making, citizenship global, information literacy, media literacy, and ICT literacy. Thus, the task of the teacher is how to be able to present learning so that these competencies can be achieved. One strategy that can be done is to apply ICT in learning, both through online-based learning if possible and offline by using ICT-based learning media. Thus, teachers in the $21^{\text {st }}$ century must be literate about the development of ICT.
\end{abstract}

Keywords $-21^{\text {st }}$ century, competencies, ICT

\section{INTRODUCTION}

The rapid development of technology in the 21 st century today demands that the educational environment be improved to match the competencies needed by students to live in the future. To deal with this, a concerted effort is required to address the transition of skills required in technology as well as higher order thinking skills such as critical thinking, problemsolving, communication, collaboration, and creativity and innovation [1].

The change in the learning paradigm in the $21^{\text {st }}$ century is actually in order to prepare the Indonesian people to be able to compete in rapidly developing technological advances. The twenty-first century skills must be possessed by actors in the field of education, both by teachers and students. During the Covid-19 pandemic in Indonesia which began in March 2020, all educational institutions were directed to conduct onlinebased learning and assessment. But in reality, there are still many students and teachers experiencing problems in implementing online-based learning. This is due to the unpreparedness of schools for the application of online learning $[2,3]$.

Hence, the main challenge in the learning process during the Covid-19 pandemic is the ICT literacy for both teachers and students. It is essential for the teachers and students in Indonesia to be literate about the ICT and its development so that the educational environment is able to produce human resources who are able to compete globally.

Based on the description above, the following problems can be formulated:

- What $21^{\text {st }}$ Century skills demands for students;

- What $21^{\text {st }}$ Century skills demands for teachers;

- How to prepare ICT literate teachers.

\section{METHODS}

This research method is a qualitative literature review sourced mainly from journals and the rest from reference books. A total of 11 articles from national journals, 5 articles from international journals, and 14 reference books have been analyzed. From a number of literatures that are grouped based 
on the problems that will be studied into three parts, as mentioned above. A number of information related to how to prepare teachers for ICT literacy was carried out by means of limited interviews.

\section{RESULTS AND DISCUSSION}

\section{A. The Twenty-First Century Skills Demands for Students}

Education, according to the Law of the Republic of Indonesia Number 20 Year 2003 [4], is "a conscious effort to prepare students through guidance, teaching, and/or training for their role in the future". It is the responsibility of the state to prepare qualified education in order to face the challenges of life that will be faced by students in the $21^{\text {st }}$ Century.

Wagner [5] explained that there were at least seven competencies and skills needed by students to face the challenges of life in the $21^{\text {st }}$ Century: (1) critical thinking and problem-solving skills; (2) agility and adaptability; (3) collaboration and leadership; (4) initiative and entrepreneurial spirit; (5) able to access and analyze information; (6) able to communicate effectively both orally and in writing; and (7) have curiosity and imagination. The Organization for Economic Co-operation and Development (OECD) explained that there were three dimensions of learning in the $21^{\text {st }}$ Century: (1) information; (2) communication; and (3) ethics and social influence [6]. Barry [7] explained that there were 10 skills needed by students to work in the $21^{\text {st }}$ Century: (1) critical thinking skills; (2) communication; (3) leadership; (4) collaboration; (5) adaptability; (6) productivity and accountability; (7) innovation; (8) global citizenship; (9) the ability and spirit of entrepreneurship; and (10) the ability to access, analyze, and synthesize information.

Partnership for $21^{\text {st }}$ Century Learning (P21) introduced the learning framework needed in the $21^{\text {st }}$ Century as seen in Figure 1 [8]. The skills needed in the $21^{\text {st }}$ Century are: (1) life and career skills consisting of flexibility and adaptability, initiative and self-direction, social and cross-cultural skills, productivity and accountability, leadership and responsibility; (2) learning and innovation skills consisting of critical thinking, communication, collaboration, and creativity; and (3) information, media and technology skills consisting of information literacy, media literacy, and information and communication technology literacy.

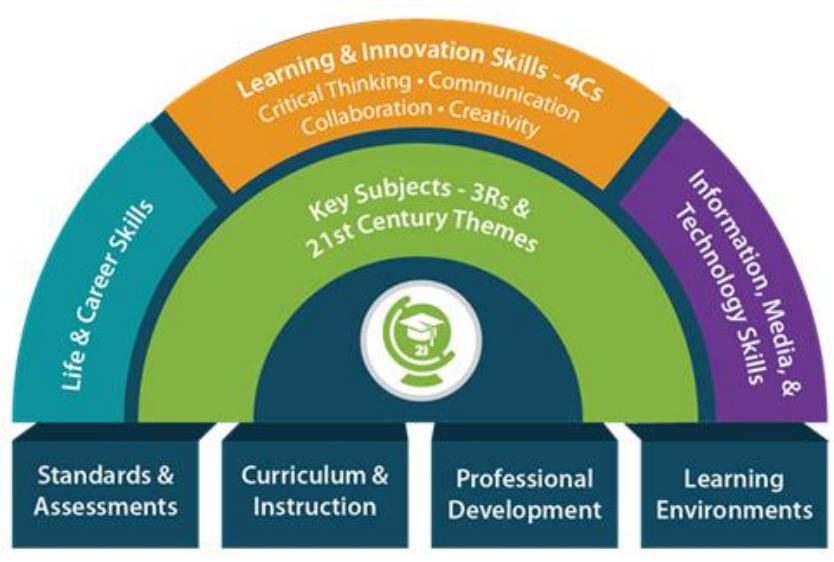

Fig. 1. $21^{\text {st }}$ century learning framework [8].

The Assessment and Teaching of $21^{\text {st }}$ Century Skills (ATC21S) classified 21 $1^{\text {st }}$ Century skills into four types: way of thinking; way of working; tools for working; and skills for living in the world [9]. Way of thinking includes problem solving, creativity, critical thinking, innovation, and decision making. Way of working includes the skills to communicate, collaborate and work in teams. Tools for working include awareness as a community both globally and locally, life and career development, and having a sense of responsibility both personally and socially. Meanwhile, skills for living in the world include information literacy skills, mastery of new information and communication technology, and the ability to learn and work through digital social networks.

UNESCO [10] explained that there were four pillars of education: learning to know, learning to do, learning to be, and learning to live together. Learning to know will teach students to seek and gain knowledge through experiences, thus triggering students to think critically. Learning to do will teach how important the interaction of students is and acts in solving problems around them. Learning to be will teach how to train students to become independent individuals and also be themselves. Learning to live together will teach that every student is a social creature and is part of a community group. Delors et al. [11] also proposed four visions of learning: knowledge, understanding, competence for life, and competence to act.

\section{B. The Twenty-First Century Skills Demands for Teacher}

The law of the Republic of Indonesia number 14 Year 2005 concerning Teachers and Lecturers [12] stated the four competencies that must be possessed by teachers, namely pedagogical competence, personality competence, social competence, and professional competence. Furthermore, the Regulation of the Minister of National Education of the Republic of Indonesia number 16 Year 2007 concerning academic qualification standards and teacher competencies [13] stated that one of the core competencies of teachers that must be possessed in professional competences is "utilizing information and communication technology to develop 
themselves". The core competencies of teachers are translated into two teacher competencies: "(1) utilizing information and communication technology in communicating; and (2) utilize information and communication technology for personal development".

To communicate, with the assistance of ICT, holds broader meaning when it is used in the learning process. As one the core competencies, teachers have to be able to gain advantages in its process, in addition to simply communicating with students via social media. By implementing online-based learning, teachers may gain more benefit through the use of ICT in communication [14]. In today's digital era, learning resources are not only limited to textbooks and teachers. In the internet, there are many learning resources that can be used by teachers for learning at school. Learners can freely access various learning resources available. The teachers' task is as a facilitator, which means directing students to achieve learning goals. Teachers can direct students by providing URL (Uniform Resource Locator) learning resources that can be used for learning.

In addition to direct access via URL, ICT-based teaching materials can also be provided by teachers to be more "contemporary", through the utilization of the Learning Management System (LMS) in managing online-based learning [15]. On the internet, there are various LMS services that can be used for free learning (open source), such as: 1) Moodle, which can be accessed through http: www.moodle.org; 2) Schoology, which can be accessed through https: www.schoology.com; 3) Blackboard Course Sites, which can be accessed through https: www.coursesites.com; 4) Latitude Learning, which can be accessed through http: www.latitudelearning.com, 5) Edmodo which can be accessed through https: www.new.edmodo.com/home; 6) Google Classroom which can be accessed via https: www.classroom.google.com, and many others.

Indonesia's diverse geographical conditions certainly lead to several areas that cannot be reached by the internet network. This condition should not become a limitation to teachers in applying ICT in their learning. Various LMS can be used offline, so that this can be a solution in the application of ICT in many areas that have not been reached by the internet network. The use of ICT in learning is not only limited to the use of the internet, but also means more than that. The application of ICT-based learning media that can be run offline is also part of the application of ICT in learning. Various learning media can be made on various computer applications so that learning becomes more interesting [16]. The use of ICT in learning is an effective and efficient way of conveying information to students. Computers as a part of ICT tools have great potential to improve the quality of learning. In some subjects in school, there is a lot of abstract or imaginative material that is difficult for students to think about, but can be displayed through computer simulations. Exploratory exercises and experiments can be carried out by students using simple programs for planting and reinforcing concepts and developing strategies in solving problems.
Halidi et al. [17] stated that through the use of information and communication technology-based media, students are prepared to interpret all information and create it into knowledge so that they can use and evaluate what is created by others. In addition, that the purpose of ICT-based learning is to increase student motivation so as not to feel bored and bored in classroom learning [18]. The enormous benefits obtained in the use of ICT in learning have also been proven by several other studies [19-25].

In today's $21^{\text {st }}$ Century, collaborative competencies must not only be possessed by students, but also must be owned by teachers. Teachers can collaborate with peers to further improve the quality of learning. In addition, collaboration can also be carried out with various other professions related to learning materials, for example with the police when discussing citizenship material, or with traders when discussing economic material. Dede [26] stated that in addition to face-to-face collaboration with peers, it can also be done in other professions that students have never encountered before.

The rapid development of ICT certainly does not have a negative effect, for example, the use of massive social media in society reduces social skills, therefore another goal of collaboration is to have social interaction between teachers, teachers and students, as well as between learners. Apart from that, the cultivation of positive characters certainly should not be forgotten by the teacher. One of the ways to cultivate character can be done by how teachers themselves apply and bring out this positive character so that students can see and imitate, because of course the adage "teacher is digested and imitated" still applies in this era.

\section{Preparing ICT Literate Teacher}

The results of a study by McKinsey \& Company showed that in Indonesia in the year of 2030, it is estimated that 23 million jobs can be eliminated due to automation and at the same time between 27 until 46 million new jobs can be created. To face this opportunity, in the current era of automation, integrated efforts are needed to overcome the transition of skills in the technology sector as well as higher-order thinking skills such as creativity and problem-solving skills, including the world of education [27].

The need for human resources (HR) in the $21^{\text {st }}$ Century must of course be adapted to the field of work that has changed drastically. One of the tasks of an educational environment is to produce competent human resources. Therefore, the educational environment must also change because the demands of work also change. Teachers as one of the main elements in the educational environment must also be at the forefront of preparing students to be competent.

The task of all parties with an interest in the educational environment is how to ensure that teachers are literate about ICT developments [28]. The government, whose holding the main responsibility in the field of education, must also make programs on an ongoing basis to improve the competence of the teachers, especially in the field of ICT. On the other hand, 
teachers should also not stand idly waiting for government assistance and programs in order to improve their competence in the field of ICT. Various self-development activities can be followed independently and can be done online.

In fact, the Indonesian government also does not remain silent in its efforts to improve teacher competence. Various online education and training programs have been implemented, such as the "Program Guru Pembelajar Online $(G P O)$ " in 2016, and the most recent is the "Program Peningkatan Kompetensi Pembelajaran (PKP)" in 2019. SIM Guru Pembelajar is an Integrated Management Information System created by the government specifically for teachers to improve the quality of their learning. To access the Student Teacher SIM, you can visit the following link: https://sim.gurupembelajar.id/gtk. The Learning Competency Improvement Program, hereinafter will be abbreviated as PKP Program, is a program that aims to improve student competence through coaching teachers in planning, implementing, and evaluating learning oriented to higher order thinking skills (HOTS) [29]. In addition, teachers who will take part in the teacher certification program are now required to join the "Pendidikan Profesi Guru (PPG)", some of which are carried out online [30].

\section{CONCLUSION}

To face life in the $21^{\text {st }}$ Century, students must have at least the following skills: critical thinking, communication, collaboration, problem solving, innovation, creativity, adaptation, initiative, entrepreneurial spirit, productivity, flexibility, accountability, self-direction, leadership, responsibility, decision making, global citizenship, information literacy, media literacy, and ICT literacy.

As the spearhead of education, teachers must also have all the skills required of students in the $21^{\text {st }}$ Century that have been outlined above. In addition to these skills, the ability to present ICT-based learning must also be mastered, for example doing online-based learning by utilizing various LMS. The ability to collaborate in learning is also important, for example by involving various other professions in learning.

The government, who's holding the main responsibility in education, must ensure that all teachers in Indonesia are literate towards ICT developments. Various online-based trainings for teachers are carried out by the government in order to increase the ability of teachers in using ICT for the learning, for example the online learning teacher program (GPO), the learning competency improvement program (PKP), and the teacher professional program (PPG), as well as increasing the activity and quality of subject teacher deliberations (MGMP). In addition, teachers are also expected to have the initiative to independently improve their competencies by participating in various online-based training conducted by both government and private institutions.

\section{REFERENCES}

[1] AACTE, 21st Century Knoledge and Skills in Educator Preparation AACTE Publishing, 2010.

[2] A. Hutahuruk and R. Sidabutar, "Kendala Pembelajaran Daring Selama Masa Pandemi di Kalangan Mahasiswa Pendidikan Matematika: Kajian Kualiatatif Deskriptif," SEPREN: Journal of Mathematics Education and Applied, vol. 2, pp. 45-51, 2020.

[3] A. Anugrahana, "Hambatan, Solusi dan Harapan: Pembelajaran Daring Selama Masa Pandemi Covid-19 Oleh Guru Sekolah Dasar," Scholaria: Jurnal Pendidikan dan Kebudayaan, vol. 10, pp. 282-289, 2020

[4] Republic of Indonesia, Act. No. 202003 on The National Education System

[5] T. Wagner, Overcoming the Global Achievement Gap (online) Cambridge, Mass.: Harvard University, 2010.

[6] K. Ananiadou and M. Claro, 21st Century Skills and Competences for New Millennium Learners in OECD Countries.OECD Education Working Papers, No. 41. Paris: OECD Publishing, 2009.

[7] M. Barry, What skills will you need to succeed in the future? Phoenix Forward. Tempe, AZ: University of Phoenix, 2012

[8] Partnership for 21st Century Skills, 21st Century Skills, Education \& Competitiveness. A Resource and Policy Guide, 2008. [Online] Retrieved from: https://files.eric.ed.gov/fulltext/ED519337.pdf

[9] P. Griffin, B. McGaw, and E. Care, Assessment and Teaching of 21s Century Skills. Dordrecht: Springer, 2012.

[10] UNESCO, Learning: The Treasure Within. Report the Unesco of the International Commission on Education for the Twenty-first Century. France: Unesco Publishing, 1996.

[11] J. Delors, I. Al Mufti, I. Amagi, R. Carneiro, F. Chiung, B. Geremek, W. Gorham, A. Kornhauser, M. Manley, M. Padrón Quero, M-A. Savané, K. Singh, R. Stavenhagen, M. Won Suhr, and Z. Nanzhao, Learning: The Treasure Within: Report to UNESCO of the International Commission on Education for the Twenty-First Century. Paris UNESCO, 1996.

[12] Republic of Indonesia, Act. No. 142005 on Teachers and Lecturer

[13] Republic of Indonesia, Regulation of Indonesian Minister of National Education No. 162007 on Qualifications and Competency Standards for Teachers

[14] S. Ghavifekr and W.A.W. Rosdy, "Teaching and learning with technology: Effectiveness of ICT integration in schools," International Journal of Research in Education and Science (IJRES), vol. 1, pp. 175191,2015

[15] A. Aldiab, H. Chowdhury, A. Kootsookos, F. Alam, and H. Allhibi, "Ulitiztion of learning system (LMS) in higher education system: a case review for Saudi Arabia,” Energi Procidia vol. 160, pp. 731-737, 2018.

[16] Z. Zainuddin and C.M. Keumala, "Blended Learning Method Within Indonesian Higher Education Institutions," Jurnal Pendidikan Humaniora, vol. 6, pp. 69-77, 2018.

[17] H.M. Halidi, S.N. Husain, and S. Saehana, "Pengaruh Media Pembelajaran Berbasis TIK terhadap Motivasi dan Hasil Belajar IPA Siswa Kelas V SDN Model Terpadu Madani Palu," E-Jurnal Mitra Sains, vol. 3, pp. 53-60, 2015

[18] S. Mashuri. Media Pembelajaran Matematika. Yogyakarta: Deepublish, 2019.

[19] D. Abrianto and H. Sitompul, "Penggunaan Media Pembelajaran Berbasis Komputer Dan Sikap Inovatif Terhadap Hasil Belajar Teknologi Informasi Dan Komunikasi,” Jurnal Teknologi Informasi \& Komunikasi Dalam Pendidikan, vol. 1(1), pp. 50-62, 2014

[20] A. Gunawan, "Pemanfaatan Teknologi Informasi dan Komunikas melalui Penggunaan Media Pendidikan dalam Pembelajaran IPS SD," Pedagogi Jurnal Penelitian Pendidikan, vol. 3, pp. 16-24, 2016.

[21] Idris, "Efektivitas Penggunaan Teknologi Informasi Dan Komunikas Dalam Pembelajaran Pendidikan Agama Islam," Jurnal Potensia, vol. 14, pp. 175-190, 2015. 
[22] R. Khairunnisa, "Penggunaan Media Berbasis Teknologi Informasi dan Komunikasi (TIK) dalam Peningkatan Kemampuan Menulis Puisi Siswa Kelas III B SDN 005 Awang Long Samarinda," Jurnal Pendas Mahakam, vol. 2, pp. 100-107, 2017.

[23] Riasnelly, "Efektivitas Penggunaan Media Teknologi Informasi dan Komunikasi (TIK) Dalam Kemampuan Menyusun Kalimat Pada Anak Tunarungu di SLB Tanjung Pinang,” E-JUPEKhu, vol. 1, pp. 122-133, 2013.

[24] Y. Roza, "Analisis Penggunaan Teknologi Komunikasi dan Informasi Pada Sekolah di Kota Pekanbaru Provinsi Riau,” Jurnal Pendidikan, vol. 1, pp. 1-7, 2010.

[25] B. Sunarwan, "Pola Penggunaan Teknologi Informasi dan Komunikasi (TIK) di Lingkungan Masyarakat Pedesaan (Survei pada Komunitas Anggota Penerima PNPM Provinsi Jambi)," Jurnal Studi Komunikasi dan Media, vol. 17, pp. 149-162, 2013.
[26] C. Dede, Comparing frameworks for 21 st century skills. In J. Bellanca \& R. Brandt (Eds.), 21st century skills: Rethinking how students learn (pp. 51-76). Bloomington, IN: Solution Tree Press, 2010.

[27] K. Das, P. Wibowo, M. Chui, V. Agarwal, and V. Lath, Automation and The Future of Work in Indonesia: Jobs Lost, Jobs Gained, Jobs Changed. Partnership for 21st, McKinsey \& Company, 2019.

[28] G. Falloon, "From digital literacy to digital competence: the teacher digital competency (TDC) framework," Education Tech Research Dev, vol. 68, pp. 2449-2472, 2020

[29] The Ministry of Education and Culture's of the Republic of Indonesia GTK Program Service Portal, 2020. [Online] Retrieved from: https://gtk.belajar.kemdikbud.go.id/

[30] A. Daud, Novitri, and M. Hardian, "Evaluation of the teacher professional education program (ppg): english students' perspective," AL-ISHLAH: Jurnal Pendidikan, vol. 12, pp. 185-200, 2020. 